\title{
The Analytical Perspective of Refugee Protection and Civil Society
}

\section{Feischmidt, Margit, Pries, Ludger and Cantat, Celine (eds.) (2019) Refugee Protection and Civil Saciety in Europe. Budapest and Bochum: Palgrave Macmillan. XX, 399 pages.}

The goal of this publication is to shed light on the vital role of civil society in tackling the global migration crisis of our days. To achieve this goal, the authors use various approaches, each specific to their topic. Through more than 390 pages, this book gives us most complex and much-needed scholarly insight into the field of migration studies. The structure and topics of the book connect it to a previous thematic issue of Intersections, published in 2016 with the title Global Migration Crisis and Europe:

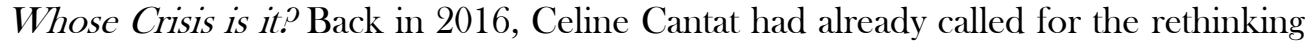
of solidarity and struggles beyond the narratives of crisis (Cantat, 2016:11).

Understanding the refugee crisis from a transnational perspective has become vital since some 1.5 million refugees entered the European Union in 2015-2016. It became clear then that neither European nation states nor European systems of refugee protection could cope with such a large influx of migrants. As Pascouau stated, 'the magnitude of migration flows arriving in the EU has reached an unprecedented peak. With more than 1 million people entering the EU in 2015, the phenomenon has been considered and qualified as a "crisis"' (Pascouau, 2016: 17). In comparison to those refugees who arrived at the borders of Western Europe in the 1990s to escape from the Balkan Wars, the 2015 wave of migrants arrived not only in significant numbers (UNHCR, 2015b: 62-66), but their reception, assistance, and allocation among the Member States of the European Union placed an especially large burden on the state administration of all countries at the receiving end of these migration routes.

The question was not whether the European Union should let these asylumseekers into the so-called territory of the European Union, but how to manage the process itself while maintaining a sufficient level of human rights and offering accentuated protection to vulnerable people until they were cleared to reach their places of settlement. Volunteers and civil society organizations started working with traditional aid groups such as the Red Cross to decrease pressure, and to offer satisfactory protection, thereby creating linkages between the states and the refugees.

The magnitude of this situation can also be observed through the United Nations calculations regarding the world's demographic expansion (see Azahaf, Kober and Mayer, 2015), which state that 'by the year 2050, (wider) Europe's working age population would decline by 96 million. Conversely, Africa's working age population 
would increase by 919 million and Asia's population by 517 million' (Mayer and Mehregani, 2016: 35).

In the introductory chapter of this book, Ludger Pries delineates the four main characteristics of the refugee movements (p. 4): the first pillar is public perception and discourse; the second is the utmost importance of civil society as a crucial actor; the third is defined as the meso-level of organizations between individuals and the state (p. 6); and the fourth and final parameter involves seeing the refugee crisis as a learning opportunity. These four factors highlight the importance of civil society. As Pries states, '...for the first time in Europe and in refugee movements, civil society was a crucial actor in almost all European societies' (p. 5).

To understand the importance of the connection between civil society movements and refugee protection, it is first imperative to distinguish crucial aspects of civil society itself, primarily within the European Union. Patrick Heller's 'three theoretical strands' (Heller, 2007) is the closest depiction. The three perspectives accord with the current state of civil societies throughout Europe. The liberal or first perspective (1) describes civil movements as 'intrinsically beneficial for democracy and society' (Cohen and Arato, 1992; Hall, 1998; Putnam et al., 1993). This point of view covers those Western-European countries that are the spearhead of refugee protection policies and actions. With a strong civil background, a country can maintain an innate balance between state and society, pursuing reformist motives. The second perspective (2) which can used to describe most of the Central-Eastern European region is that civil society is a required 'tool' which contributes to regimechange in a specific region or country. The main attribute of this type of democratization is that it can establish more centralized and concentrated political capability (Molnár, 2016) which is discernible through radicalising polities and populist actions, both of which are seen throughout Central and Eastern Europe. The third perspective (3) is somewhat isolable from the two above, mainly because of its critical nature. This perspective is that almost all populist movements (and later, parties) benefitted from the radicalism of their civil societies (Kovács, 1994), and vibrant civic life largely contributed to the rise of right-wing ideas and movements. It is important to mention that this perspective denounces Putnam's social capital thesis and all neo-Tocquevillean theories by claiming that when democracies are fragile, higher levels of democratization can lead to illiberalism (Molnár, 2016). Accordingly, in the case of migration and refugee protection, the three perspectives are adaptable; for example, in the case of post-socialist countries 'civil society has emerged as the main arena in which the symbolic repertoire of a new nationalism is articulated' (Molnár, 2016: 170, quoting Feischmidt et al., 2014, and Trencsényi, 2014). Nonetheless, the aforementioned factors are allied to a country's migration policy, especially in the European Union. The gravity of civil society is recognized as a general connective thread throughout the chapters.

That being said, each part of the book contains a valuable, specific insight from a unique viewpoint in addition. Further on in the first chapter, Pries states that 'the overall framing of refugee protection shifted from "there are problems in the Middle East and Africa" to "we are part of a global constellation where people are forced to flee their homes" (p. 5). The role of civil society movements was no longer in the second line, but as active participants - and in many cases, local governments and 
authorities were in need of this active participation and recognized the former NGOs as experts with considerable migrant-aid-specific knowledge and infrastructure. The refugee crisis can be considered a trigger for a humanitarian response from which one can learn important information about humanity as a whole. Pries warns us that there is a tendency to marginalize the contribution of civil society (its instrumentalization by governments), but also an inclination to overestimate the role of civil society in refugee protection (p. 18).

In Chapter 2 ('Networks of Refugee and Asylum Related Organizations in the Mediterranean Area of the European Union'), Juliana Witkowski, Ludger Pries, and Anna Mratchkowski highlight the fact that in spite of the development of the Common European Asylum System (CEAS), its actual implementation has not been successful. Notwithstanding the gestures of welcome from civil society, NGOs, and countries such as Austria and Germany, it has become clear that Europe has struggled with the large number of asylum-seekers and has not been able to cope with the development of events, at least not with the methods and systems that were used before. This assumption is based on that fact that even though the European Union has broadly progressive refugee policies, their implementation is frail and does not match up to reality. In response to this, the MAREM-project (Mapping Refugees' Arrivals at Mediterranean Borders) came to life to act as a 'gap-filler' between local governments and NGOs. The project connected different countries that faced the same, continuous flow of refugees (such as Cyprus, Greece, Italy, Malta and Spain, cf. p. 31) and became an example of cross-national and transborder cooperation. International multidisciplinary cooperation in the Mediterranean area is 'the crucial pillar [...] of the management of refugee protection' (p. 51).

The authors of Chapter 3 ('Politics of Care and Compassion: Civic Help for Refugees in Hungary - A Mixed Methods Approach'), Margit Feischmidt and Ildikó Zakariás, focus on the philanthropic aid provided to refugees crossing Hungary between the spring and autumn of 2015. In spite of the governmental discourse that was somewhat distorted into a sense of ambiguity regarding general safety, a humanitarian component was also strongly present. This indicates a strongly opposing relationship between charity and politics; a claim here primarily based on data collected between October 2015 and January 2016 by the Hungarian Academy of Sciences (p. 60). Positive affect arose in both those who directly helped refugees (e.g. at train stations, or near the Hungarian border), and in those who were informed of these events from a more distant perspective via so-called 'shared experience.' The overall outcome was generally positive emotions and not only the rediscovery of a sense of humanity, but through this an increasing awareness of political responsibility (p. 89) - which is called the 'politicization of charity.' Under these circumstances, charity can also become an alternate form of public responsibility; this process is known as the 'charitization of politics.'

In Chapter 4 ('Subversive Humanitarianism and its Challenges: Notes on the Political Ambiguities of Civil Refugee Support'), Vandevoordt and Verschraegen emphasize that the professional literature on this subject largely presumes the political nature of the actions it studies, which can lead to the creation of a grey area between politics and morality (p. 102) - mostly because at the time of the 'crisis' there were a vast number of people whose intentions and political beliefs were widely estranged, 
thus creating contradictory phenomena. Also, numerous governments throughout Europe discouraged migrants from entering their countries, but civil workers acted differently by helping those in need, thereby distinguishing themselves from the acting governments. One may draw a parallel here, since one of the critiques of humanitarian aid is that 'it produces a hierarchical, power-infused relation between providers and recipients' (p. 108). This can also be called a 'grey area,' mainly because those who were in charge of letting numerous asylum-seekers into their countries often based their evaluations on intuition.

In Chapter 5 ('Opportunistic Humanitarianism and Securitization Discomfort Along the Balkan Corridor: The Croatian Experience'), Župarić-Iljić and Valenta conclude that during the constant flow of migration Croatia was only a transit country for asylum-seekers on their way to the 'core' of the European Union (p. 130); a claim which resonates with the Croatian government's official rhetoric. The authors clarify that both governmental and civil actors were in constant motion, providing care and assistance for migrants. After the critical events in Paris and Cologne, authorities started to close their border corridors, which gradually led to the work of humanitarian organizations becoming detached from that of the Croatian government. This led to a situation where the latter pro-refugee actors who constantly sought to engage in acts of helping found themselves opposing their own governments. In this chapter, one may notice descriptions of acts of 'civil resistance' against official state approaches.

In Chapter 6 ('Becoming, Doing and Letting Go: (Extra)Ordinary Citizens' Engagement with Resettled Syrian Refugee Families in Rural France'), Schiff and Clavé-Mercier concentrate on the UNHCR resettlement program which helped transport those Syrian families who were placed in various asylum-seekers' refuges in rural France. The authors highlight two important aspects of the former practice: one is the integration of these asylum-seekers into French society, while the second is the success of the resettlement program itself, making cultural integration the most important factor of all. The authors' assumption is that there are specific local dynamics which influence the ways in which people engage with refugees (p. 162). Nevertheless, in many cases the refugees' behavior, culture, religious views, norms about gender equality, and basic education of children and women are completely different from those of their local supporters; many on the receiving end of the integration program called these differences problematic. As one of them stated (p. 190) "we realize that our priorities may not be the same as their priorities - we have accomplished our mission, but have we succeeded?"

In Chapter 7 ('Gender and Intimate Solidarity in Refugee-Sponsorships of Unaccompanied Young Men'), Paul Scheibelhofer focuses on the relationships between the receiving 'foster' families and those young men who were chosen to work / integrate into their new places in 'Western' society. He states that there is a negative discourse about the young male refugees that often claims they are a threat to the safety of women and public order. In spite of the fact that during a sponsorship program the refugees constantly received emotional, material, and social resources, this could not disguise the elementary differences between the host families and those arriving from an entirely different culture. One dilemma is that the whole situation started with a position of dependency on the side of those who arrived, which often 
led to the severing of arrangements before they even started. The analysis also states that 'refugee-sponsorships are a highly dynamic form of civic engagement' (p. 213), but the former structurally dependent position seems to be especially hard to overcome. Scheibelhofer concludes that receiving refugees is not a 'toned-down' experience, as it always ends up in a more personal relationship which represents another aspect of humanity.

Chapter 8 ('The Welcomers: How Volunteers Frame Their Commitment for Refugees') examines the political aspects of the volunteering movement. Here, Karakayali argues (p. 237) that helping refugees is an act of political resistance in relation to the general political atmosphere. In 2015, during the peak of events, volunteering and humanitarian activism was undertaken by German citizens who had never participated in these kinds of events before. Closer analysis reveals that the political component of helping refugees refers to that part of civil-society that 'can use "integration" to connect with segments of the local society [...] which otherwise remain distant from any form of activities in support of migrants' (p. 238).

Chapter 9 ('Volunteer, Citizen, Human: Volunteer Work between Cosmopolitan Ideal and Institutional Routine') describes how the number of refugees arriving in Europe has been steadily increasing since 2015, putting the receiving governments and local public administrations in a difficult position. As the authors Theresia Turinsky and Magdalena Nowicka highlight, the refugee crisis represents a chance to redefine current political and social structures with a 'gesture of humanity' (p. 244). As a Neighbourhood Helps (NH) program participant stated, the main hub for migration aid, Berlin, is a cosmopolitan, non-national place that connects people from all around the world, irrespective of their current citizenship. On the other hand, the authors emphasize the fact that the commitment and awareness of their participants is not enough to successfully transform moral assumptions and ideas into an institution-based framework.

As Wyller puts it in Chapter 10 ("“Something More”: The Citizenship Performativity of Religiously Founded Refugee Projects'), true citizenship comes into existence when people who may or may not hold the passport of a specific country act in a humanitarian way, thereby creating 'citizenship of the world.' Wyller explains that in spite of local governments' attempts to reduce the numbers of asylum-seekers, churches and various religious organizations were amongst those institutions that resisted the restrictions most vigorously. This may be based on the idea that, according to typical religious beliefs, the most common acts of kindness are a means of elevating individuals to a higher level of existence. Humanity, as such, persists because humans offer succor to fellow humans. Events such as Pope Francis's visit to Lampedusa in 2013, Lund in 2016, and the Bergsjøen Congregation in Gothenburg show us that, irrespective of religion, people always can and will work together for the sake of humanity.

According to Povrzanović and Mäkelä, volunteering can help transcend the limitations of the ego, and thus can represent humanity's ultimate act. Within the framework of Chapter 11 (“"Only Volunteers”? Personal Motivations and Political Ambiguities within the Refugees Welcome to Malmö Civil Initiative'), the authors analyze volunteers' experiences with refugees and conclude that the former created especially deep and human bonds with the migrants. Also, as the Civil Initiative 
referred to in the chapter slowly became an NGO, it built bridges between the helpers and asylum-seekers, deepening the bond between them and thus making society more tolerant and open (p. 313).

The local governments of Sweden, the country that received the highest number of unaccompanied asylum-seeking children (UASC) and youth in comparison to its population (p. 319), were subject to an especially significant burden in terms of organizing the everyday lives of migrants while striving to continuously uphold their human rights during the asylum-seeking process. In Chapter 12 ('Contestations of the Swedish Deportation Regime: Civil Mobilisation for and with Afghan Youth') Asztalos Morell highlights that the website Stop the deportation of Afghan youth! which came into existence brought together volunteers and the youth who were affected by this struggle. She states that the Stop Deportations network is the perfect example of how helpers and those who are in need can be brought together in our 'information age' (p. 346).

As Olivier-Mensah explains in Chapter 13 ('Refugee Social Work Positioned Between Transnationalization, State Services and Volunteering: A Review from the German Context'), since 2015 over one million people have fled to Europe, and multiple strategies have been implemented by the European Union and also by nation states to handle this. In connecting the cooperation between social work and civil society volunteering, Olivier-Mensah colligates those initiatives which helped migrants during the asylum process in Germany. As she states (p. 370), 'volunteerism often converges with political activism, going hand in hand with social development and the transformative power of change' (with reference to Chapter 3 by Feischmidt and Zakariás, p. 60). This transformative potential could be an additional element in transforming a political or societal system into a more humanitarian one in a more hostile environment.

In the last chapter ('Conclusion: Civil Involvement in Refugee ProtectionReconfiguring Humanitarianism and Solidarity in Europe') Cantat and Feischmidt conclude that the power of humanity, diversity, and hope once again brought humans together to help those who were in dire need of help. They claim that it is important to 'identify the criteria to determine who is worthy of protection and care' in line with the necessary norms (p. 397), and to realize that providing guidance for one group does not necessarily mean that others are no longer in need, especially in European cultures (e.g. homeless people, minorities, and the poor, who are currently living at the margins of our societies in Europe).

From the perspective of conceptualization and methodologies, the book occupies a peculiar place in the field of migration-related literature, mostly because it consists of a mix of different but also rather crucial multidisciplinary approaches. The extracted findings were based on several types of data and various research techniques. There were online surveys (Karakayali and Kleist, 2015; 2016), individual and group interviews, and also the direct approach of volunteering initiatives, associations, and organizations. Occasionally, survey statistics were based on two sets of samples which helped the researchers to compare data-sets diachronically (see, for example, the chapter by Karakayali, p. 225).

While Feischmidt and Zakariás focus on a pro-refugee civic initiative in Hungary, the perspective of humanitarianism also appears in the studies of 
Verschraegen, Karakayali and Vandervoordt with a special focus on solidarity and volunteering. In the case of highly skilled migrants, Olivier-Mensah and Frykman describe the importance of transnational social work by addressing the current issues of refugee- and labor migration. This issue is also present in Chapter 12, where Asztalos Morell inspects the pro-EU migrant movements and civil mobilization in Sweden, along with Makela in the case of the 'Refugees Welcome To Malmö' initiative. Struggles for integration that go beyond the narratives of the crisis specifically appear in a chapter by Schiff and Clavé-Mercier, who address the matter of ethics and solidarity. In connection with this, Cantat, Feischmidt, Nowicka, Mratchkowski and Turinsky not only review intersectional diversity, but engage with the delicate subject of migrant-non-migrant relationships and cosmopolitanism. The interpretation of spatial amplitude in connection with migration ethics, gendered racism, and hate crimes from the perspective of sociology is the specific area of research of Pries, Schiebelhofer, Valenta, Witkowski, Župarić-Iljić and Wyller, with Wyller also expanding his scope to the field of ecclesiology.

As it is perceptible throughout the chapters, we can also conclude that civil society functions at its finest when it becomes collective action (Edwards, 2004). In the case of migration, joint action turned out to be the impact factor of the cross-country support programs that were organized to handle refugee issues and, due to this, civil society represented an important counterpoint to radicalism in the European Union. The lesson here may be that by relying on the common values of humanity - even if they are challenged - one can avoid distrust and doubt. This book is not a mere addition to the vast migration-related literature, but creates a new foundation for this area of research. The broad perspectives and opinions contained herein may serve as a useful starting point for conducting or even starting one's own projects. Due to its multidisciplinary approach, this book could be especially useful to researchers in the fields of history, sociology, and cultural anthropology, and also to volunteers; further, to anyone seeking to deepen their knowledge and compare different aspects of the related phenomena.

ÁDÁM CSÁKY

International Strategy Office of Eütvös Loránd University

\section{References}

Cantat, C. (2016) Rethinking Mobilities: Solidarity and Migrant Struggles Beyond Narratives of Crisis. Intersections, 2(4): 11-32. https://doi.org/10.17356/ieejsp.v2i4.286

Cohen, J. and Arato, A. (1992) Civil Society and Political Theory. Cambridge, MA: MIT Press. 
Feischmidt, M. (ed.) (2014) Nemzet a mindennapokban. Az újnacionalizmus populáris kultúrája. (Everyday Nation: The Popular Culture of NeoNationalism.) Budapest: L’Harmattan, MTA Társadalomtudományi Kutatóközpont.

Hall, J. A. (1998) The nature of civil society. Society, 35(4): 32-41. https://doi.org/10.1007/BF02686380

Heller, P. (2007) Democratic Deepening in India and South Africa. Journal of Asian and African Studies, 44(1): 123-149. https://doi.org/10.1177/0021909608098679

Karakayali, S. and Kleist, O. (2015) Strukturen und Motive der ehrenamtlichen Flüchtlingsarbeit in Deutschland. Berlin: BIM. Available at https://www.bim.huberlin.de/media/2015-05-16_EFA-Forschungsbericht_Endfassung.pdf Accessed 14-04-2016

Karakayali, S. and Kleist, O. (2016) Strukturen und Motive der ehrenamtlichen Flüchtlingsarbeit in Deutschland 2. Berlin: BIM. Available at https:/www.bim.hu-berlin.de/media/2015-05-16_EFA-

Forschungsbericht_Endfassung.pdf Accessed 07-02-2016

Kovács, M. (1994) Liberal Professions and Illiberal Politics: Hungary from the Habsburgs to the Holocaust. New York: Woodrow Wilson Center and Oxford University Press.

Mayer, M. M. and Mereghani, M. (2016) Beyond crisis management: The path towards an effective, pro-active and fair European refugee policy. In Vision Europe Summit: Improving the Responses to the Migration and Refugee Crisis in Europe. 30-53. Available at https://bruegel.org/wpcontent/uploads/2017/02/VisionEurope\%E2\%80\%93PolicyPapersweb.pdf Accessed 10-10-2019

Pascouau, Y. (2016) From conflict to equilibrium: The construction of a common ground for social and political consensus on migration. In Vision Europe Summit: Improving the Responses to the Migration and Refugee Crisis in Europe. 14-28. Available at

https://bruegel.org/wpcontent/uploads/2017/02/VisionEurope\%E2\%80\%93PolicyPapersweb.pdf Accessed 10-10-2019

Putnam, R., Leonardi, R. and Nanetti, R. Y. (1993) Making Democracy Work: Civic Traditions in Modern Italy. Princeton: Princeton University Press.

Ticktin, M. (2005) Policing and humanitarianism in France: Immigration and the turn to law as state of exception. Interventions, 7(3), 346-368.

https://doi.org/10.1080/13698010500268148

Trencsényi, B. (2014) Beyond liminality? The Kulturkampf of the early 2000s in East Central Europe. Boundary, 2(41): 135-152. https://doi.org/10.1215/019036592409703 
UNHCR (2015a) Global Trends: Forced Displaced in 2015. UNHCR, the UN Refugees Agency. Available at http://www.unhcr.org/statistics/unhcrstats/576408cd7/unhcr-global-trends-2015.html Accessed 11-10- 2019

UNHCR (2015b) Global Trends: Forced Displaced in 2015. UNHCR, the UN Refugees Agency. Annex Table 2. Refugees, asylum-seekers, internally displaced persons (IDP s), returnees (refugees and IDP s), stateless persons, and others of concern to UNHCR by origin | end-2015. Available at www.unhcr.org/globaltrends/2015-GlobalTrends-annex-tables.zip Accessed 1110-2019

Virág, M. (2016) Civil society, radicalism and the rediscovery of mythic nationalism. Nations and Nationalism, 22(1): 165-185. https://doi.org/10.1111/nana.12126 